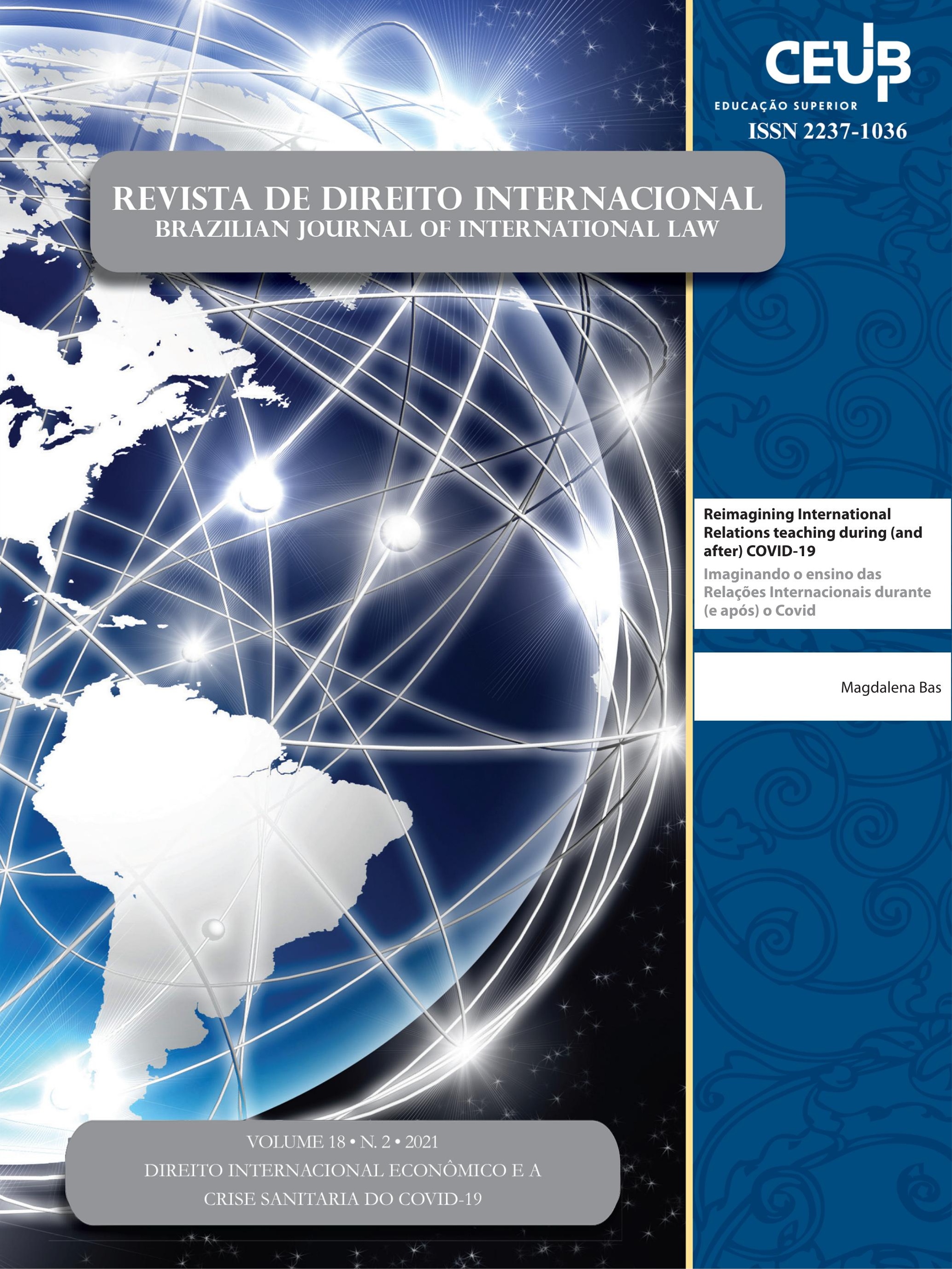




\section{Sumário}

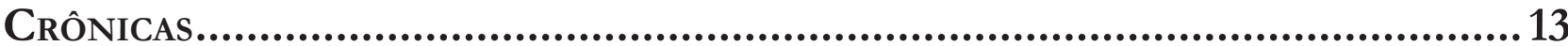

REIMAgining INTERNATIONAL RELATIONS TEACHING DURING (AND AFTER) COVID-19 ........15 Magdalena Bas

Dossiê Temático: Direito Internacional Econômico e a Crise sanitaria Do COVID-19 (INTERNATIONAL ECONOMic LaW AND THE COVID-19 SANITARY CRISIS) 19

Some QUESTIONS ABOUt INTERNATIONAL ECONOMic LAW RAISED DURING THE PANDEMIC .....21 Hervé Ascensio

International Economic LaW and the COVID-19 Sanitary Crisis: An Introduction 27 Julien Chaisse

TransparênCIA E COOPERAÇão REgUlatóRIA No COMÉRCIO INTERNACIONAL DE PRODUTOS MÉDicos PaRa a COVID-19: uMa ANÁlISE da ATUAÇão INSTITUCIONAL DA OMC E DAS NOTIFICAÇõES do Brasil EM OBSERVÂNCIA AOS ACordos TBT E SPS .35

Magali Favaretto Prieto Fernandes e Michelle Ratton Sanchez Badin

O DEVER HUMANO DE PROMOÇÃo DA SAÚDE: A AVIAÇÃo COMERCIAL INTERNACIONAL EM PERÍODOS DE CALAMIDADE SANITÁRIA E DO RETORNO À NORMALIDADE .56

Thiago de Oliveira Frizera, Luisa Cortat Simonetti Gonçalves e Adriano Sant'Ana Pedra

Police Powers Doctrine: a reliable State Defense in times of Covid-19?.... .73 Thomas Lehmann

A inexistênCia do Controle preventivo legislativo de Convencionalidade da Medida Provisória n. ${ }^{\circ} 936 / 2020$ .91

Danilo Garnica Simini, Gabriel Carvalho Moreira e Rafaela Souza Machado 
A Critical analysis of the implications of Covid-19 on piracy off the Nigerian COAST

Kalu Kingsley Anele

The COVID-19 PANDEMIC AS AN IMPELlER FOR THE AGgRAVATION OF MARINE PLASTIC POLLUTION AND ECONOMIC CRISIS: THE REVERSE EFFECT OF HEALTH PROTECTION MEASURES ON HUMAN LIVES 135

Adriana Isabelle Barbosa Lima Sá Leitão e Tarin Cristino Frota Mont’Alverne

Artigos sobre outros temas

O Direito Internacional Humanitário nos Pareceres Consultivos da Corte Internacional de Justiça: uma Conjugação de Perspectivas Utópicas e Apologéticas 156

Talis Prado Pinto Junior e Arthur Roberto Capella Giannattasio

Contesting immunities in the International Criminal Court: an analysis of the RUlings of the Pre-Trial Chambers and the Appeals Chamber in Al Bashir Case and its OUTCOMES. 171

Luisa Giannini e Roberto Vilchez Yamato

Rumo à Profissionalização da Prevenção de Controvérsias nos Acordos de CooperaÇão e Facilitação de InVEstimentos (ACFIs) do Brasil? 191

Nitish Monebhurrun e Leonardo Vieira Arruda Achtschin

THE PREVENTIVE CHARACTER OF DISASTER LAW: TAX INCENTIVES IN ENVIRONMENTAL, SOCIAL, AND GOVERNANCE (ESG) INVESTMENTS AS A RISK MITIGATION MECHANISM 212

Daniel Dela Coleta Eisaqui e Deilton Ribeiro Brasil

A URGÊNCIA DE UM MODELO DE GOVERNANÇA INTERNACIONAL DA ÁGUA: ELEMENTOS PARA A DISCUSSÃO

José Irivaldo Alves Oliveira Silva

O FIM DA HIERARQUIA SUPRALEgAL DOS TRATADOS INTERNACIONAIS: ANÁLISE DA ADI N.O 5.543/2020-DF: À luZ dA TeOria ARgumentativa de Neil Maccormick. 
Os DIREITOS HUMANOS FRENTE À NORMATIVIDADE “IMPERIAL" E A RESPONSABILIDADE DAS EMPRESAS TRANSNACIONAIS POR VIOLAÇÃO AOS DIREITOS HUMANOS NA ERA DO “IMPÉRIO” 280

Fernando Hoffmam e Jose Luis Bolzan de Morais

O RECONHECIMENTO FACIAL NAS SMART CITIES E A GARANTIA DOS DIREITOS À PRIVACIDADE E À PROTEÇÃO DE DADOS PESSOAIS.. 302

Diogo Dal Magro e Vinícius Borges Fortes

O DESENVOLVIMENTO HISTÓRICO DA PROSCRIÇÃo DO DESAPARECIMENTO FORÇADO DE PESSOAS E sua fenomenologia no Direito Penal Internacional e no Direito Internacional dos Direitos Humanos

Marcus Vinícius Xavier de Oliveira

CONSTITUCIONALISMO COOPERATIVO GLOBAL E DIREITO INTERNACIONAL PRIVADO: INSTRUMENTOS PARA UMA GOVERNANÇA DE DIREITO TRANSNACIONAL NA INTEGRAÇÃO. 362

Anderson Vichinkeski Teixeira, Roberto Correia da Silva Gomes Caldas e Luciane Klein Vieira

Proteção da inovação pela aplicaÇão do Direito da ConcorrênCia da União Europeia: ANÁLISE DA INDÚSTRIA FARMACÊUTICA.

Pablo Leurquin 


\title{
Reimagining International Relations teaching during (and after) COVID-19*
}

\author{
Imaginando o ensino das Relações \\ Internacionais durante (e após) o Covid
}

Magdalena Bas**

\section{Teaching and learning International Relations in the COVID-19 era}

Teaching and learning International Relations is challenging, as international phenomena must be addressed at the time they develop. However, virtual teaching and learning in the COVID-19 era involve extra challenges, even more in massive courses (approximately 140 active students). Thus, firstly this piece aims to examine the author's experience as a professor of International Relations at the University of the Republic (Uruguay) during 2020-2021. In light of the above, the second part of the article presents some guidelines to reimagine International Relations teaching the day after the syndemic ${ }^{1}$.

\section{Challenges and lessons learnt}

The first challenge to tackle in order to reach "virtual" meaningful learning $^{2}$ is getting to know the students and avoid falling into an "allegory of the cave". That is, believing that students have certain characteristics based on assumptions according to age or where they live. The context of massiveness can mask individualities. However, there are always opportunities to inquire into their interests, look for opinions and reflections, support them during formative and summative evaluations, and even in the development of digital skills.

Coordination within the teaching team is essential to maintain fluid communication through forums. Digital space can also turn into a "natural critical learning environment", in terms of Bain ${ }^{3}$, in which the fear of raising doubts or making mistakes is mitigated. Getting to know students also provides information to improve the writing of assessments instructions

* Recebido em 01/09/2021

Aprovado em 20/09/2021

** Postdoctoral Researcher at the Institute of Human Rights and Business of the University of Monterrey (UDEM), Mexico. Professor at the University of the Republic, Uruguay. Member of the National Researchers System, Uruguay

Email:magdalenabas@gmail.com or "frequently asked questions", especially useful in summative evaluations.

\footnotetext{
The term syndemic, coined by Singer, is used to include the social and political conditions and effects in addition to the health related to the pathogen. SINGER, Merrill. Introduction to syndemics. A critical systems approach to public and community health. San Francisco: Jossey-Bass, 2009.

2 AUSUBEL, David. Significado y aprendizaje significativo. In: AUSUBEL, David; NOVAK, Joseph, HANESIAN, Helen (ed.). Psicología Educativa: un punto de vista cognoscitivo. Ciudad de México: Trillas, 1976.

3 BAIN, Ken. What the Best College Teachers Do. Boston: Harvard University Press, 2004.
} 
Approaching the role of the professor from this perspective strengthens the construction of what Bruner called "scaffolding"4.

The second challenge is to maintain students' motivation during times of demotivation. Diversity in assessments and approaches to International Relations are two fundamental keys. Regarding the first, both in 2020 and 2021, we included Kahoot, Mentimeter, and Moodle quizzes and the resolution of cases to bring the professional practice into the classroom ${ }^{5}$.

Regarding complementary activities, it was particularly noteworthy the recording of the podcast "(Re) Armando las Relaciones Internacionales" -“(Re)assembling International Relations"-, whose first episode was dedicated to Mercosur ${ }^{6}$. This innovation project was led by Assistant Professor Valentina Starcovich, and although it originated in the 2021 course, it continued after it. The use of third-party podcasts is also a possible option, for instance: “¿Cuál es el plan?” (Uruguay); "Aletheia" (Argentina), "Observatório do Regionalismo" (Brazil), or "The Economist Asks" (United Kingdom).

New approaches towards and from International Relations can also help maintain motivation in the understanding that they present views to which the students are not used to ${ }^{7}$, for instance, the aesthetic turn in the field ${ }^{8}$. Analysis of images (photographs, cartoons, or illustrations) or series and films contributes to new interpretations and interdisciplinary work. Likewise, these activities constitute fertile ground for the profes-

\footnotetext{
${ }^{4}$ BRUNER, Jerome. The role of dialogue in language acquisition. In: SINCLAIR, Anne; JARVELLA, Robert; LEVELT, Willem (ed.). The Child's Concept of Language. New York: Springer-Verlag, 1978, p. 254.

5 The four dilemmas in the resolution of practical cases in Public International Law, extendable to other related disciplines, can be seen in BAS, Magdalena. Trabajar con casos prácticos en Derecho Internacional Público. Una historia de cuatro dilemas. Revista electrónica de Derecho Internacional Contemporáneo, La Plata, v. 2, n. 2, p. 17-23. 2019. Examples of practical cases and other exercises can be consulted LABORÍAS, Alexis Rodrigo. Derecho Internacional Público. Ejercitaciones y documentos. Buenos Aires: Temas Grupo Editorial, 2013.

6 Available in Spotify.

For other examples see: BAS, Magdalena; NIEVES, Mónica. Tejiendo las Relaciones Internacionales: desafíos de la enseñanza de la disciplina. In: MEMORIAS de ponencias de las X Jornadas sobre Enseñanza del Derecho, Centro para el Desarrollo Docente, Facultad de Derecho, Universidad de Buenos Aires, p. 266-272. 2020.

8 BLEIKER, Roland. Mapping visual global politics. In: BLEIKER, Roland (ed.). Visual Global Politics. New York: Routledge, 2018. p. 1-29. BLEIKER, Roland. The aesthetic turn in international political theory. Millennium: Journal of International Studies, London, v. 30, n. 3, p. 509-533. 2001.
}

sors to build cognitive bridges between the students' prior knowledge (a series that they have already seen, a photograph that they already know, academic knowledge acquired in another subject) and new knowledge to be incorporated, reaching a meaningful learning objective?.

Finally, the last challenge is to contextualise learning without losing sight that the students will be professionals the day after this syndemic ${ }^{10}$. Global International Relations' perspective, in the words of Acharya and Buzan $^{11}$, allows incorporating a plurality of themes and approaches. Furthermore, it is useful to introduce the study of the COVID-19 crisis' different dimensions, as well as other view of traditional topics such as the relevance of the politics of International $\mathrm{Law}^{12}$ or the increasing power of transnational corporations ${ }^{13}$ even in times of retreat from hyper-globalisation ${ }^{14}$.

Consequently, the teaching-learning process requires materials from different sources, which contribute to the field from different views. In both editions of the course, we introduced the analysis of press articles as non-traditional texts in the classroom ${ }^{15}$. The evaluation format was also innovative as students had to record an audio file of 60 seconds maximum. In this way, learning competencies related to synthesis capacity, oral communication, adaptability, or critical

\footnotetext{
9 Regarding previous perceptions, foreign policy and television series, see: HOLLAND, Jack. Visual Literacy in International Relations: Teaching Critical Evaluative Skills through Fictional Television. International Studies Perspectives, v. 17, n. 2, p. 173-186, May. 2016. 10 For further analysis see: BAS, Magdalena. Enseñar relaciones internacionales en tiempos de covid-19: desafíos didácticos desde la enseñanza virtual. Análisis Carolina, 35/2020. Madrid: Fundación Carolina. 2020.

11 ACHARYA, Amitav; BUZAN, Barry. The Making of Global International Relations: Origins and Evolution of IR at its Centenar. Cambridge: Cambridge University Press, 2019.

12 KOSKENNIEMI, Martti. The politics of International Law. Oxford: Hart Publishing, 2011.

13 STRANGE, Susan. The Retreat of the State: The Diffusion of Power in the World Economy. New York: Cambridge University Press, 1996.

14 RODRIK, Dani. The Globalization Paradox: Democracy and the Future of the World Economy. New York: WW. Norton, 2011.

15 Press analysis required an investigation, although limited, by the student. For further analysis on student research in areas related to International Law in general or related fields see: MONEBHURRUN, Nitish. Pensando na articulação entre a internet como instrumento de pesquisa jurídica e o rigor acadêmico. Revista Opinião Jurídica, v. 14, n. 19, p. 147-170. 2016.
} 
thinking could be assessed.

\section{The day after COVID-19}

Although the majority of non-traditional resources or activities that we used during COVID-19 lessons were previously available, their use was not generalised. The syndemic made visible what was invisible, as Sassen argues ${ }^{16}$. Thus, adaptation, creativity, and planning were the key ideas to address the challenges and put those resources into practice. Are they applicable to teaching the day after the syndemic? Can we recycle them in order to reimagine teaching after COVID-19? Despite that the syndemic is a turning point in higher education, the experience gained will allow better planning and building of active teaching spaces in face-to-face and virtual classrooms as well as hybrid modalities -for example, flipped classroom-. In the latter, the focus should be on the necessary balance so that the virtual instance does not become an artificial extension of the face-to-face one.

Specifically in the field of International Relations, in addition to planning and didactic innovation, two other elements are fundamental in order to reimagine the teaching-learning process. The first one is to accept that the transformations that take place in the international order "chime intimately on the way we build our knowledge", as Acharya and Tussie ${ }^{17}$ argue. The contents of a subject are not static; syllabus revision does not only imply permanent bibliographic updates but also the incorporation of new topics and trends. Even so, the revision may be insufficient if it does not embrace gender perspective as well as scholars from non-Western or Global North countries. This is what Tickner and Weaver ${ }^{18}$ called "worlding beyond the West", an approach that contributes to building "situated knowledge" from Latin America ${ }^{19}$.

\footnotetext{
16 KEVE, Carolina. Entrevistas Dipló - Saskia Sassen: "Podemos pensar esta pandemia como una oportunidad para entender más y mejor las injusticias de nuestro sistema". Le Monde Diplomatique Edición Cono Sur, 2021.

17 ACHARYA, Amitav; TUSSIE, Diana. Latin America and the Caribbean in Global International Relations. In: ACHARYA, Amitav; DECIANCIO, Melisa; TUSSIE, Diana (ed.). Latin America in global international relations. New York: Routlegde, 2021. p. 1.

18 TICKNER, Arlene; WEAVER, Ole (ed.). International Relations scholarship around the world (Worlding beyond the West). New York: Routledge, 2009.

19 Seitz, Ana Mirka. Relaciones Internacionales desde América
}

Secondly, the future (and present) of International Relations teaching leads to building towards and from its contours because complex issues require approaches from the core and the margins. The knowledge generated in the intersections with other fields, such as Economics, History, Law, Political Science, Sociology, or Visual Studies, allows a more complete understanding of the international facts, a non-fragmented researching agenda and teaching with a broad, innovative, and inclusive view. In short, analysing the challenges posed by teaching International Relations in the COVID-19 era is also an invitation to reimagine the field and its didactics.

\section{References}

ACHARYA, Amitav; BUZAN, Barry. The Making of Global International Relations: Origins and Evolution of IR at its Centenar. Cambridge: Cambridge University Press, 2019.

ACHARYA, Amitav; TUSSIE, Diana. Latin America and the Caribbean in Global International Relations. In: ACHARYA, Amitav; DECIANCIO, Melisa; TUSSIE, Diana (ed.). Latin America in global international relations. New York: Routlegde, 2021.

AUSUBEL, David. Significado y aprendizaje significativo. In: AUSUBEL, David; NOVAK, Joseph, HANESIAN, Helen (ed.). Psicología Educativa: un punto de vista cognoscitivo. Ciudad de México: Trillas, 1976.

BAIN, Ken. What the Best College Teachers Do. Boston: Harvard University Press, 2004.

BAS, Magdalena; NIEVES, Mónica. Tejiendo las Relaciones Internacionales: desafíos de la enseñanza de la disciplina. In: MEMORIAS de ponencias de las X Jornadas sobre Enseñanza del Derecho, Centro para el Desarrollo Docente, Facultad de Derecho, Universidad de Buenos Aires, p. 266-272. 2020.

BAS, Magdalena. Enseñar relaciones internacionales en tiempos de covid-19: desafíos didácticos desde la enseñanza virtual. Análisis Carolina, 35/2020. Madrid: Fundación Carolina. 2020.

Latina. In: LANGÓN, Mauricio; LÉRTORA MENDOZA, Celina (coord.). La primera década del siglo XXI: Balance y perspectivas. XV Jornadas de Pensamiento Filosófico. Buenos Aires: Ediciones FEPAI, 2011. 
BAS, Magdalena. Trabajar con casos prácticos en Derecho Internacional Público. Una historia de cuatro dilemas. Revista electrónica de Derecho Internacional Contemporáneo, La Plata, v. 2, n. 2, p. 17-23. 2019.

BLEIKER, Roland. Mapping visual global politics. In: BLEIKER, Roland (ed.). Visual Global Politics. New York: Routledge, 2018. p. 1-29.

BLEIKER, Roland. The aesthetic turn in international political theory. Millennium: Journal of International Studies, London, v. 30, n. 3, p. 509-533. 2001.

BRUNER, Jerome. The role of dialogue in language acquisition. In: SINCLAIR, Anne; JARVELLA, Robert; LEVELT, Willem (ed.). The Child's Concept of Language. New York: Springer-Verlag, 1978.

HOLLAND, Jack. Visual Literacy in International Relations: Teaching Critical Evaluative Skills through Fictional Television. International Studies Perspectives, v. 17, n. 2, p. 173-186, May. 2016.

KEVE, Carolina. Entrevistas Dipló - Saskia Sassen: "Podemos pensar esta pandemia como una oportunidad para entender más y mejor las injusticias de nuestro sistema". Le Monde Diplomatique Edición Cono Sur, 2021.

KOSKENNIEMI, Martti. The politics of International Law. Oxford: Hart Publishing, 2011.

LABORÍAS, Alexis Rodrigo. Derecho Internacional Público. Ejercitaciones y documentos. Buenos Aires: Temas Grupo Editorial, 2013.

MONEBHURRUN, Nitish. Pensando na articulação entre a internet como instrumento de pesquisa jurídica e o rigor acadêmico. Revista Opinião Jurídica, v. 14, n. 19, p. 147-170. 2016.

RODRIK, Dani. The Globalization Paradox: Democracy and the Future of the World Economy. New York: WW. Norton, 2011.

SEITZ, Ana Mirka. Relaciones Internacionales desde América Latina. In: LANGÓN, Mauricio; LÉRTORA MENDOZA, Celina (coord.). La primera década del siglo XXI: Balance y perspectivas. XV Jornadas de Pensamiento Filosófico. Buenos Aires: Ediciones FEPAI, 2011.

SINGER, Merrill. Introduction to syndemic: A critical systems approach to public and community health. San Francisco: Jossey-Bass, 2009.
STRANGE, Susan. The Retreat of the State: The Diffusion of Power in the World Economy. New York: Cambridge University Press, 1996.

TICKNER, Arlene; WEAVER, Ole (ed.). International Relations scholarship around the world (Worlding beyond the West). New York: Routledge, 2009. 
Para publicar na Revista de Direito Internacional, acesse o endereço eletrônico www.rdi.uniceub.br ou www.brazilianjournal.org.

Observe as normas de publicação, para facilitar e agilizar o trabalho de edição. 